\title{
98 not-/unveiling as an ethical practice
}

\author{
Nadia Fadil
}

\section{abstract}

The practice of Islamic veiling has over the last ten years emerged into a popular site of investigation. Different researchers have focused on the various significations of this bodily practice, both in its gendered dimensions, its identity components, its empowering potentials, as a satorial practice or as part of a broader economy of bodily practices which shape pious dispositions in accordance with the Islamic tradition. Lesser, however, has this been the case for the practice of not veiling or unveiling. If and when attention is accorded to the latter, it is often grasped as a product of integration or an effect secular governmentality, but only rarely as a bodily practice. Drawing on narratives of second generation secular and religious Maghrebi Muslims in Belgium, this paper pursues this second perspective by examining to which extent not-veiling can be understood as a technique of the self (Foucault) that is functional to shaping a liberal (Musilm) subject. While a first part of this article will unpack the ethical substance of such discursive interrogations and point to the ways in which they are intertwined with the enactment of a liberal self, the second part will examine the embodied contours of this problematization, which appeared through the labour upon one's affect and bodily dispositions that this refusal of the hijab, or the act of unveiling, implies.

\section{keywords}

Not-veiling; piety; self-technique; secularism; liberal Muslims; embodiment 
'We are preparing a special issue on Islam, I want you to write an article on the veil'. I told him: 'no, the non-veil'. I called them the non-veiled of Islam. I said: 'the veil, I'm sick of it'. I told him: 'Yes, I want to write and talk about the veil. But then I'll call names because there are Muslim women who aren't veiled. And I want to speak for them, you see? I want to let them talk about themselves. (Saloua, journalist, Brussels)

Sitting in her comfortable apartment in the green suburb of Brussels, Saloua, a Belgian-Moroccan middle-aged woman with a sophisticated intellectual outlook, recounted the difficulties she encountered in making her way as a journalist since her return from Morocco, now eleven years ago. Saloua belonged to the so-called 'second generation' immigrants, a generation that was either born or had arrived at a young age in Belgium with the immigration of their parents in the 1960s. Saloua had moved to Belgium from Morocco at the age of 3, and lived there since then. At the age of 29, she decided to return to Morocco after falling in love with a man and marrying him. In the years she spent there, she gave birth to her two daughters, taught French and worked on a PhD in postcolonial and comparative literature. Yet, as her marriage proved unhappy, she eventually divorced her husband and returned to Belgium with her daughters. Since her return, she had been trying to make her way professionally as a literary critic. The difficulties she encountered in gaining access to the French literary circles had, however, led her to settle for a career as a freelance journalist, as she was regularly asked to write articles on Islam or immigration. While she initially enjoyed doing so, she quickly grew dissatisfied with the kind of themes she was invited to write on and the 'limited' perspective she could adopt - as she put it. The headscarf controversy was one of those recurrent themes she dreaded writing on, for she was deeply annoyed by the contours of the debate. The quote above illustrates this and sketches a dialogue between her and her chief editor wherein she explains her reluctance to write yet another article on the issue. Two elements are to be stressed in this refusal.

Saloua's refusal firstly reflects a postcolonial critical posture to the way the headscarf has been shaped into an emblematic symbol in the representation of Muslim women in the current post-migratory context. As a literary critic, she saw this obsessive focus on veiled women as an illustration of the Orientalist gaze on the Muslim world - which now extended to the Muslims in Western-Europe. While these imageries of the Muslim woman as essentially veiled are by no means new and find their roots in colonial discourses (Ahmed, 1992), these modes of representation have gained a new impetus in the current 'Islam debate' (Zemni, 2009), which has been raging across various Western-European countries, including Belgium, for the last ten years. By refusing to write on veiled women, Saloua seems to primarily argue against the way this garment has turned into a preferred mode of representation of Muslim women, and Muslims 'tout court'. Yet, besides denouncing neocolonial representations of Muslims, Saloua's opposition is also informed by the normative weight of the hijab as an ethical

1 The latter also illustrates the sexualised dimension of these 
neo-Orientalist imaginaries wherein women appear as main symbolic markers in the representation of a particular group see Yuval-Davis (1997).

2 I use 'veil' and 'headscarf' interchangeably to refer to this sartorial practice as a social practice and 'hijab' to describe a religious conduct or religious prescription.

3 For a critical assessment on the relationship between scholarship on Islam in Europe and the question of integration of Muslims, see AmirMoazami and Salvatore (2003); Peter (2006).
4 See, for the case of Western-Europe practice, as a religious prescription. ${ }^{2}$ This brings us to the second dimension that lies at the heart of this paper. By refusing to write on veiled women and insisting on representing the non-veiled, Saloua not only acts as a journalist who wants to deconstruct Orientalist stereotypes, but she also adopts a position of an advocate who is stirred by a desire to give more visibility to those women who, just like her, chose not to veil.

Whereas the Islamic practice of veiling (hijab) has gained a large amount of scholarly interest over the past decades, there has been less scholarly attention to those Muslim women who chose not to veil. The rapidly increasing literature on Muslims in various Western-European countries has largely focussed on the modes of life of pious and practising Muslims in general, and veiled women in particular. This privileged focus on veiled women can be largely understood against the background of the resurging societal concerns, not to say 'moral panic', that has surrounded the increasing visibility of Muslim practices in the Western-European public sphere since the early $1990 \mathrm{~s}^{3}{ }^{3}$ By examining Muslim piety in general, and the practice of veiling in particular, scholars have tended to offer a more nuanced perspective that counters popular and stereotypical representations that assimilate the headscarf to cases of docility, oppression or segregation. Several studies have shown how veiling can figure as an act of individual reappropriation of the Islamic tradition, an affirmative identity practice with potentially empowering effects for Muslim women or a sartorial practice that enables the expression of a sense of regional or national belonging in a modern and fashionable manner (Göle, 1993; Khosrokhavar, 1997; Navaro-Yashin, 2002; Amir-Moazami, 2007; Moors and Tarlo, 2007). Recent studies have also examined the religious functionality of the headscarf, and the way this religious conduct (hijab) fits into a broader system of pious conduct, such as praying, adopting a particular code of conduct, and so forth (see Mahmood, 2001 and 2005; Amir-Moazami and Jouili, 2006; Bracke, 2008). Yet by limiting this research angle to veiled Muslim women, the idea of veiling as an idiosyncrasy that needs to be explained or accounted for is unwillingly confirmed. Restricting the analysts' lens to orthodox Muslim conduct like veiling, and leaving other forms of (pious) conduct unexplored, results indeed in a situation wherein only practices that fail to correspond with 'secular ways of life' are turned into the object of research. Hence, while the numerous sociological and ethnographic studies on the headscarf seek to normalise practices such as the headscarf, its single analytical problematisation ironically reinforces its isolation.

This paper proposes to shift the analytical focus from veiling to not-veiling. In doing so, it firstly seeks to contribute to the emerging - yet embryonic literature on 'liberal' and 'secular Muslims' by offering a succinct ethnographic account of some second generation Belgian-Maghrebi women who choose not to veil. ${ }^{4}$ The narratives explored here are the result of fieldwork conducted between 2003 and 2006 in the Belgian cities of Antwerp and Brussels among Islamic and 
socio-cultural Maghrebi networks. Sixty-five interviews were conducted with seventeen men and forty-eight women, all second generation Belgian-Maghrebi immigrants and active in the civil society. As children of low-skilled immigrants, they all shared a working class background, but most of them achieved social mobility either through their studies or through their employment in civil society. The respondents were selected through direct contact during my participation in meetings and through snowball sampling. Whereas the spectrum of the interviewed respondents ranged from very pious and orthodox to non-practising and non-religious, I restrict myself here to the analysis of the interviews with those women who tried to live Islam 'differently' - as some of them put it. This 'difference' was articulated in the way they challenged a number of prescriptions (such as the hijab), sexual mores (such as the prohibition on pre-marital sexual intercourse), or by questioning the centrality of rituals in ethical conduct.

The analysis will focus less on the various motivations for Muslim women not to veil, but more on the practice of not-veiling. In what follows, I will argue that not-veiling can be understood as an aesthetic of the self that is intimately tied to the formation of a particular kind of moral (Muslim) subject, one that is primarily structured by liberal ethical grounds. While the first part of the paper will set out the contours of this discussion within the Belgian context and the literature, the third and fourth parts of the paper will explore the way this problematisation of the hijab can be viewed as a form of ethical self-fashioning. ${ }^{5}$ Such a perspective invites us, I suggest, to denaturalise a perspective on the body that views not-veiling as a 'natural' state of being, and to explore the complex agency of non-veiled Muslim women in the current post-migratory context wherein forced unveiling has turned into one of the preferred modes of disciplining Muslims.

\section{the Belgian headscarf controversy and new configurations of the secular}

The presence of the Maghrebi community in Belgium is largely situated against the background of post-World War II labour migration waves. In 1964, Belgium signed bilateral agreements with Morocco and Turkey, and few years later with Tunisia (1969) and Algeria (1970). While the 1964 treaties resulted in a substantial immigration of Moroccan and Turkish workers to Belgium, only few Tunisian and Algerian workers would find their way to Belgium. Currently, the Moroccan-Maghrebi community represents the largest non- $\varepsilon U$ minority in the country estimated at 220,000 (Kanmaz and Battui, 2004), and is the largest group within the Muslim community, estimated at 400,000. What started as a temporary immigration of unskilled workers would gradually lead to the settlement of a new religious and cultural minority. This new demographic and social reality would, however, largely remain 'invisible' in the national
Amiraux (2006), Mas

(2006), Fernando

(2009); for the case of the Middle-East Al-Ali (2000).
5 The notion of problematisation is borrowed from Michel Foucault. In his introduction to the second volume of History of

Sexuality (1992

[1984]) he views

the field of problematisation as an effect of power, and frames it as the interrogation of certain behaviours and conducts in a particular moment of history that are reflective of particular regimes of truth. 
6 For a further account of the coupling between the electoral success of the right wing and the politicising of the multicultural society, see Jacobs (1998), Jacobs and Swyngedouw (2002), Blommaert and Verschueren (1992).

7 In 1989, a number of schools in Brussels prohibited the headscarf. See Goethals, Michèle (s.d.) 'De Hoofddoek. Te nemen of te laten' in CIE Website: http:// www.flw.ugent.be/cie/ CIE/goethals l.htm\#2l.

8 As a federal state, Belgium does not have a national public sphere for all media and civil society is organised along the linguistic border. For a more elaborate discussion and overview of the headscarf controversy in the different Belgian linguistic regions, see Longman (2003) and Coene and Longman (2008).

9 The latter not only applies to the veil, but equally to the financing of the Islamic cult (mosques, Imams) or the question of Islamic schools. I will, however, in the context of this paper limit myself to a brief discussion of the headscarf and the face-veil.

10 At the time of our writing, the imagination until the early 1990s, despite the official recognition of Islam as a national cult in 1974. The early 1990s coincide with the electoral successes of the right wing Flemish nationalist party Vlaams Blok (since 2004 Vlaams Belang) in 1989. This party gained electoral successes with its separatist agenda and the explicit coupling of social problems with multiculturalism. Moroccans, as the largest non- $\varepsilon U$ minority, figured as the main target of their anti-immigration rhetoric. ${ }^{6}$ These developments furthermore coincided with a new political conjuncture on an international level (with the Cold War ending and the emerging 'clash of civilization' paradigm focused on 'political Islam'), which translated in Western-Europe as an increasing focus on the 'internal Muslim threat' exemplified in the UK through the Rushdie affair, and in continental Europe through the headscarf issue.

The headscarf debate in Belgium has been highly influenced and guided by the waves of its southern neighbour, France. Already in 1989, one can find traces of the French uproar in some Belgian public schools. ${ }^{7}$ It is, however, only with the second French 'veil controversy', which started in 2003, that a large headscarf debate would equally take place in the different Belgian linguistic regions. ${ }^{8}$ As opposed to its neighbouring country France, Belgium is not characterised by of a unified secular model (laïcité) but rather constituted by a constellation of often conflicting ideological perspectives, ranging from adherents of the French laïcité principle to Catholic and non-Catholic defenders of the public role of religion. Whereas a principle of neutrality reflects the state's necessity to remain distant from religious expressions, an active participation of religious (Catholic) organisations in the institutional landscape of the country, especially in the Northern region of Flanders, figures as an important hallmark of the country (Panafit, 1999). As of today, large parts of the Belgian civil society (trade union, hospitals, political parties, NGOs) are organised along confessional lines, and Catholic schools represent more than 70 per cent of the total educational system in Flanders and around 50 per cent in Wallonia. Yet in recent years, this heterogeneous secular model has undergone a number of transformations and found new points of articulations around the increasing public visibility of Muslims, with the headscarf controversy as the most concrete illustration. ${ }^{9}$

While the recent headscarf controversy has not resulted in the adoption of a general law, the societal debates led to a sociological reality wherein the majority of public and Catholic schools de facto prohibit visible religious signs at school. In September 2009, the board of the public schools of the Flemish community (Het Gemeenschapsonderwijs) also adopted a general regulation against visible religious signs for pupils and teachers, which was scheduled to take effect in September 2010, yet did not at the time of writing due to a number of legal contestations. The measure was indeed highly contested, not only by the opponents of the ban who successfully challenged it, ${ }^{10}$ but also by school principals who saw this measure as a breach of the principle of the autonomy 
of the schools, a well-established convention that privileges the right of schools to decide individually upon such matters. ${ }^{11}$ The general ban, therefore, signalled a rupture with the prevailing church-state relations in the educational system, announcing a shift from a bottom-up to a more centralist and top-down approach.

A second illustration of such transformations can be found in the recently voted 'burqa-law'. France and its national debate on the face-veil and the national identity in the fall of 2009 figured here, yet again, as an important trigger. Belgium, however, overtook its southern neighbour by being the first to adopt a restrictive law on face-veiling in April 2010. ${ }^{12}$ The measure was adopted almost unanimously (with the exception of one vote) by the federal chamber, just a few hours after the resignation of the federal government due to failed negotiations between the Francophone and the Flemish on institutional reforms. The simultaneity of both events is not anodyne I suggest, but reflects a contradictory development of institutional fragmentation and cultural homogenisation that has been characterising the country in the last years. ${ }^{13}$ The fact that a law on the face-veil was so quickly passed at a time of institutional crisis, without any preceding discussions, illustrates how a degree of 'we-ness' seems to be fostered throughout an exclusion of the 'abject'. Discussing the work of Julia Kristeva on abjectness, Judith Butler notes how this sense of radical otherness (the abject) expresses the establishment of a coherent sense of the self through boundary drawing, or by expelling parts of its composition to the outside: 'the "abject" designates that which has been expelled from the body, discharged as excrement, literally rendered "Other"' (Butler, 1990: 169). The exclusion of faceveiled women as 'abject other' enables a minimal sense of 'we-ness' in the fractured Belgium but also in other Western-European countries where citizenship is increasingly cast in cultural terms - a tendency Annelies Moors equally observed in her discussion of the Dutch face-veil controversy (2009: 395).

\section{not-veiling as an aesthetic of the self}

Stating that non-veiled Muslim women are absent from the literature on Muslims in Europe and/or the West is not entirely accurate. While few studies have accounted for this group as a sociological category (Read and Bartkowski, 2000; see also Herrera, 2000 for Egypt), non-veiled women have often been put forward as the neutral or integrated alter ego of their veiled sisters. This is especially the case in the literature that examines the integration process of Muslims in Europe. Here, generic categories such as 'silent majority' or 'Islam tranquille' are used to depict those Muslims whose practices conform with the dominant societies (Saint-Blancat, 1997: 10; see also Kepel, 1994). The implicit assumption adopted here is that not-veiling follows from a gradual adaptation to prevailing European secular worldviews, whereas veiling indicates a disruption. legitimacy of this measure was still being deliberated at the level of the Constitutional Court after a negative appraisal of the Belgian State

Council (Conseil

d'etat/Raad van

State), that

questioned its

constitutional legitimacy.

11 See 'Panta Rhei verzet zich tegen hoofddoekenverbod', De Standaard, 03/ 10/09; 'Heel blij dat we nog een jaar kunnen doorgaan', De Standaard, 12/09/10.

12 See 'Kamer keurt verbod op het dragen boerka goed', $D e$ Standaard, 29/04/10.

13 The Belgian federal government has been

encountering a number of crises over communitarian questions since the elections of 2007 , which have led to a governmental paralysis that lasted for half a year. 
Nancy Venel's Musulmans et Citoyens (2004) forms a good illustration of this kind of reasoning. In her qualitative study, she differentiates four types citizenship conceptions among the young Muslims she interviewed ('Francais pratiquants', 'accomodateurs', 'contractants' and 'neo-communautaires'). In the group 'les Français 'Pratiquants' [practicising French], she includes Muslims who are strongly attached to their French identity and reject public manifestations of religious conduct: 'They are more Muslim in a cultural sense than in a religious one, and most of them maintain a distant relationship to Islam. They manifest a quasi-religious devotion to France and its Republican principles' (Venel, 2004: 35 - my translation). Veiling is viewed here as a breach of the principles of laïcité, and a strong emphasis is put on the necessity to live unnoticed and in step with French society: 'to be like everybody, and dress like everybody' (Venel, 2004: 26 - my translation). Perspectives like those of Venel have the advantage of offering a complex view on the religious trajectories young Muslims may adopt. Yet by primarily grasping this diversity in relation to their 'Frenchness', this analysis fails to overcome a problematic one-dimensional understanding of integration that builds on a juxtaposition between the adherence to dominant citizenship notions (conceived in secular terms) and the Muslim identity. This not only leads to a notion of integration understood as assimilation, but it also tends to (re)affirm the idea of not-veiling as a neutral or passive conduct.

Counterbalancing this first approach, a recent perspective has tended to insist on the implicit or explicit set of regulations behind the non-veil. The regulative ideals and disciplining procedure underpinning notions of dominant citizenship are unpacked, and the idea is abandoned within this critical perspective that not-veiling figures as an effortless adaptation to prevailing liberal and secular values. Such approaches have allowed for an understanding of the headscarf ban as a body politics of secular governmentality that seeks to regulate Muslim female conduct according to specific notions of nationhood (Asad, 2006; Scott, 2007; Gökariksel, 2009; Jouili, 2009; Kejanlioglu and Tas, 2009; Moors, 2009). The neocolonial dimensions underpinning these regulations are furthermore also underlined, especially in the way these measures currently target second or third generation descendants of those who had been subjected to similar procedures under the French or British colonial rule (Yegenoglu, 1998; Rahbari, 2000; Mas, 2006; Fernando, 2009: see also Fanon, 1964; Ahmed, 1992; Lazreg, 1994). Not only have cases of institutional or forced unveiling been analysed through this lens, but also standpoints that reflect a critical posture vis-à-vis the headscarf. In a recent analysis of the Ni-Putes-Ni-Soumise icon and self-declared secular Muslim Fadela Amara, the anthropologist Manyanti Fernando (2009) offers an analysis of the ways Amara's secular standpoints and opposition to the headscarf mirror the subjective positions crafted by the French Republican model. Being less interested in the individual motives of Amara, Fernando rather seeks to analyse 
the 'political, discursive, and ideological conditions undergirding, even compelling, the appearance of secular Muslim women' (2009: 380).

Whereas this second, critical, perspective has crucially allowed for a disclosure of the power dynamics behind the non-veil, I argue that the tendency to tacitly reduce oppositions to the headscarf to these dynamics is equally problematic. This appears clearly in the way the individual motives of secular Muslims like Amara are disregarded in place of an analysis of the historical, epistemological or discursive conditions undergirding their viewpoints. By failing to offer an exploration of the various motivations behind the non-veil, and by ascribing the latter to strong opponents to the headscarf, the complexities of the agency of women who choose not to wear the headscarf is not only bypassed, but one also risks reducing contemporary oppositions to the headscarf in Western-Europe to a continuation of neocolonial and nationalist policies. The agency of the nonveiled Muslim women thus risks being viewed as a case of compelled assimilation, and any opposition to the veil understood as a willing or unwilling complicity with disciplinary procedures against (orthodox) Muslims.

While placing Muslim women's opposition to veil in a wider historical and discursive context remains essential, I argue that it cannot simply be reduced to it. In making this point, I depart from the necessity to differentiate between a situational approach, which tries to locate practices within a specific power matrix, and an explanatory approach, which reduces these practices to the latter. The notion of 'situatedness' entails indeed the idea that all practices veiling and not-veiling - need to be positioned within distinctive power structures. ${ }^{14}$ Yet by only locating the agency of the non-veiled in the disciplinary operation of 'the secular', a perception is implicitly adopted that ignores the way veiling and not-veiling are implicated by this same power structure. The popularity of the headscarf among Muslim youth in Western-Europe (and the Middle East) can indeed equally be viewed as a reaction to secularist and neocolonial policies, and thus reduced to these power structures. This perspective has been adopted by scholars who have explained the popularity of the veil by pointing to the role of anti-colonial authenticity movements such as Islamist movements (Lazreg, 2009) or by viewing it as an affirmation of Muslim identity politics (Göle, 1993; Khosrokhavar, 1997; Roy, 2000; Amiraux, 2003). This perspective has, however, rightfully been challenged in its incapacity to account for the ethical agency of Muslim women and their references to the Muslim normative tradition (Mahmood, 2001). I, therefore, advocate a complex notion of agency that not only looks at the ways power structures regulate subjects, but also at the complex ways individuals inhabit these power structures (Foucault (1992 [1984]); Mahmood, 2005; see also Butler, 1990). This means, applied to our case, that one should examine the complex ways in which secular normativity is inhabited, reproduced and/or contested by those who refuse to veil, and its interactions with the Muslim ethical tradition.
14 In using the term 'situatedness' I draw on Haraway's (1988) conceptualisation that reflects the necessity to situate knowledge production against distinctive contexts and power structures. 
15 This critique resonates with Foucault's critique on the tendency to limit the analysis of the operation of power/knowledge to the institutional political game or the juridical system (see Foucault, 1998 [1976]).
In what follows, I will attempt to apply these insights by looking at the ways in which the practice of not-veiling can be understood as an aesthetic or technique of the self. This notion draws on a Foucaultian vocabulary that tends to grasp how individuals shape themselves into moral agents. In the second volume of The History of the Sexuality, Foucault defines the latter as: 'techniques which permit the individual to effect, by their own means, a certain number of operations on their bodies, on their own souls, on their own thoughts, on their own conduct, and this in a manner so as to transform themselves, modify themselves, and to attain a certain state of perfection, of happiness, of purity, of supernatural power, and so on' (Foucault, 1980: 203; see also Foucault, 1984: 27). The primary aim of this analytical displacement is not only to offer a more complex account of the wide range of motivations that exist behind the non-veil, or to show that not-veiling cannot simply be reduced to cases of assimilation or forced adaptation. This perspective also offers, I suggest, an analytical added value in understanding the operation of 'the secular' that trespasses a politico-juridical understanding of power, and rather engages with a microphysics of power that uncovers the various ways in which a secular-liberal discursive regime is reproduced throughout one's daily discourses, habits and conducts. $^{15}$

Yet, besides enabling a more complex view on the operation of 'the secular', such a perspective also allows us to uncover the affective, material and discursive labour implied in the non-veil, and the way the latter is tied to a certain ethical labour upon the self. While ritual practices like praying, fasting or veiling have recently been analysed as techniques of the self (see Asad, 1993; Mahmood, 2005; Jouili, 2007; Jouili and Amir-Moazami, 2006; Jacobsen, 2010), this perspective has not yet been applied to the case for the non-veil. I suggest that these theoretical insights can help us to de-naturalise the non-veil, and situate it as a technique of the self that is tied to the formation of a particular Muslim moral self and which, in some cases, implied an effort upon one's affective household and corporeality.

\section{problematising the hijab}

Leyla, a 21-year-old student in Arabic philology of Tunisian background, comes from a home where Islam was lived intensely, yet 'without seeing evil everywhere', as she put it. She spoke highly of the way her mother and her deceased father, who was an Islam teacher, lived their piety. While her parents pushed her and her sibling to fulfil a number of religious duties (such as praying and fasting), she never experienced any strict coercion or rigidness from them. It was rather a 'positive Islam', as she put it, an Islam that insisted on the love of God and goodness as a sense of ethics. This 'positive Islam' contrasted sharply with the messages she encountered during her quest of religious knowledge. Over the last 
years, she had attended to a number of seminars, gatherings and discussion groups with the hope of strengthening her theological background and her piety. Yet the 'narrow' views she experienced there - as she put it - either on sexuality, the position of the women, or the rigid conception on piety, put her off and even led her to question God and Islam: 'I don't need religion if it's, if it's something ... I don't need God if it's a bad God. Sometimes I feel guilty saying things like this'. A continuous self-interrogation traversed her at the time of our interview, and she was deeply tormented by the question of whether she could 'live' Islam in a 'different' way than what she saw around her and still remain a 'good Muslim'. The prescription to veil (hijab), and the consensus among scholars, as well as within the community, figured as one of her major preoccupations.

The veil, it's one of the major problems of my life (laughs). It's not that it's a problem, it's that I don't understand it. I don't see its utility actually. Now, maybe I should learn more about Islam, read the Qur'an completely, maybe, know more about stuff. But actually, I don't listen to people. I can't believe in it. It might seem incredible, because well, everybody wears it, and for everybody [it's like] you have to wear it. But I don't see its logic. (...) What's its purpose? (...) First thing that I felt was like: 'I have to veil, and I will wear it once, but not now'. And then I started, well I told to myself: I should dress in a particular way, not to draw attention etc. So I tried. So that was the first step - veiling, maybe one day. And then I started thinking about the veil, as such. And to look at veiled women. And my first impression was that (...) it was an instrument to annihilate the personality of women. Voila. (Leyla, student, Brussels)

In the abovementioned quote, Leyla sets out the different phases she traversed regarding the hijab. While she was initially convinced of its mandatory nature, this position gradually shifted over the years to her current position where she views the headscarf as an oppressive, sexist 'instrument'. Leyla was not alone in her interrogations. Huda, a community worker from Antwerp, explained that she had stopped wearing the headscarf, which she had been obliged to wear by her parents, during her studies. The main reason for this was that she grew increasingly unconvinced of its religious utility: 'for me, that headscarf wasn't the proof of ... It didn't mean that: "yeah, you are virtuous or pious because of it". I still believe in God, and I will always pray, but that headscarf is only a symbol for me'. Safa, a policy advisor of a regional Minister, was also not convinced of a religious benefit from this practice: 'I don't see it as a must, as something I have to do in my religious experience. I can be faithful without the headscarf'.

The status of the hijab figured as an important preoccupation for both veiled and non-veiled women I encountered during my fieldwork in Brussels and Antwerp. This concern firstly resonates with the 'headscarf controversies' that have been taking place in Belgium since 2003 (see above). Yet besides 
16 For an illustration of how the questioning of the hijab corresponds with a broader hermeneutical enterprise and advocates a different reading of the religious sources and distances itself addressing this public controversy, these interrogations of the hijab also resonated with discussions within the Muslim tradition (Mernissi, 1975; Ahmed, 1992; El Guindi, 1999; Babès, 2004; Mir-Hosseini, 2007; Lazreg, 2009). In using the notion of tradition, I draw on Talal Asad's usage of the term that he defines as 'discourses that seek to instruct practitioners regarding the correct form and purpose of a given practice that, precisely because it is established, has a history' (1986: 14; see also Amir-Moazami and Salvatore, 2003). While Muslim conduct is not to be reduced to religious prescriptions, Asad stresses, the Islamic discursive tradition does act as a guideline for what counts as 'apt performance' and 'how the past is related to present practices', (1986: 15). The Muslim tradition is, however, not understood in a homogeneous way, but is rather viewed as a discursive arena that is traversed by a set of conflicting perspectives over what counts as 'good practice' (Asad, 1986: 15). In these different approaches, Asad differentiates between the 'orthodox' viewpoints, which have the power to 'regulate, uphold, require or adjust correct practice, and to condemn, exclude undermine or replace incorrect ones', and lessorthodox standpoints (1986: 15). 'Orthodoxy' refers here less to rigid or conservative viewpoints, and more to a set of epistemological procedures, discourses and practices (usul-al-fiqh) in the development of Islamic knowledge that is considered authoritative, and thus is given a prescriptive legitimacy. These procedures consist among others of a particular understanding of the foundational texts, that is the Qur'an (as the word of God) and the Sunna (as second mandatory source), the abidance to the consensus (ijma') for Sunni Islam and the reasoning by analogy (qiyyas). While some have disputed the explicit mentioning of the hijab in the Qur'an ( $\varepsilon$ l Guindi, 1999: 154; see also Babès, 2004; Lazreg, 2009), there exists a consensus among orthodox scholars across all religious schools (madahab) that this dress is a religious duty (fard). Questioning the obligatory nature of the hijab therefore means challenging the dominant consensus, and thus also means placing oneself in a position of marginality vis-à-vis the Muslim orthodoxy. Such heterodox viewpoints on the hijab often also converge with a modernist hermeneutical perspective that views religious sources primarily as 'historical' texts that need to be deconstructed in the light of a specific temporal and spatial context, and which challenges the hermeneutical power of religious scholars by underlining the individual's capacity to engage directly with the texts (ijtihad). ${ }^{16}$ It is at this latter dimension that I wish to pause to reflect at more length and focus particularly on the very distinct notion of the 'self' that is articulated throughout the interrogations of my respondents.

Leyla's resistance to the hijab stems from her inability to understand the pertinence of this prescription and her refusal to rely on other people's viewpoints in her spiritual quest - 'I don't listen to people' she often repeated. 
The change she describes in the above-mentioned quote illustrates a shift from a pious self-conception that is informed by a set of obligations - "I have to veil' - to a self-conception wherein one's assessment becomes central 'I started to think'. Huda and Safa equally insist on their capacity to judge and assess the religious scriptures and evaluate for themselves what counts as pious conduct. ${ }^{17} \mathrm{~A}$ model of piety seems thus to be articulated wherein the Self acts as main legislator for one's ethical conduct. Religious practices are primarily performed to the extent that they correspond with one's 'will' or 'rationality'.

My intention here is not to suggest that Muslim women who question the hijab have a greater capacity for critical reflection than those who do not. Besides being prejudiced, such a presupposition would also sit at odds with my theoretical and epistemological assumptions that take such rationalistic selfconceptions as an object of analysis rather than a point of departure. My purpose rather lies in understanding how such interrogations are functional to the enactment of a particular notion of the Self. By questioning the prescription to veil, my non-veiled respondents were simultaneously articulating a distinct subjectivity model that has turned dominant - not to say: hegemonic - within modernity: a liberal mode of subjectivation. Within this perspective, the Self is conceived as a self-grounding subject whose agency is primarily realised throughout the capacity to live in accordance with one's 'rationality' or the 'truths' one finds within oneself (Foucault, 1993 [1980]); Taylor, 1989; Mahmood, 2005). This model does not imply the refusal of any form of external authority, but it does suggest that this obedience should be the result of one's (rational) agency, something Andrew Reath coined the sovereignty thesis: 'agents subject to moral requirements must be regarded as their legislators and the source of their authority' (2006: 123). The subject that is thus realised becomes the subject of freedom (Rose, 1999), or the individualised subject that is involved in a continuous set of 'existential self-problematization', to use Mitchell Dean's formulation (1999: 61). By questioning the hijab, Leyla, Huda and Safa are not only advocating a different, non-orthodox, understanding of piety, but these interrogations also stem from their cultivation of a specific religious agency, one that is primarily structured along liberal ethical lines.

These liberal notions of the self can be contrasted with some other narratives that I encountered during my fieldwork, wherein one's self-fashioning process was geared towards a different teleology: that of obeying God. Zeina, a pious woman in her thirties, was actively involved in the Muslim civil society in Brussels at the time of our interview. Of Tunisian background, she grew up in France but moved to Belgium after her marriage to her (ex-)husband. During our conversation, she stressed that Islam was not something that had been transmitted to her, but rather something she 'discovered' at the age of 16 , almost by accident, after bumping into Yusuf Al-Paradawi's 'Al Halal wa'l Haram from the orthodox theological corpus, see Babès (2004).

17 Also important is the semantics through which Huda frames the veil: as a symbol. This vocabulary introduces us to a modernist perspective on rituals understood as 'symbolic expressions' of religious systems and interiority. For a theoretical exploration of different notions of ritual, see Talal Asad, Genealogies of Religion (1993, especially 78-79). 
18 An observation that has for the first time been analysed and unpacked in a very fine manner by Saba Mahmood (2005) in her seminal Politics of Piety. The Islamic Revival and the Feminist Subject (see also Hollywood, 2004; Bracke, 2008).

19 Linda Herrera (2000) observes in Egypt the emergence of this phenomenon of 'downveiling' among some Egyptian women in Cairo in the late 1990s, which she views as a symptom of a more general process of 'relaxing of socio religious practices'. For the women she spoke with, unveiling had little to do with religious reasons, but more with practical or even aesthetic matters.

20 It is important to fi'l Islam' [The authorised and the prohibited in Islam]. Since this discovery, her main purpose in life had been to strengthen her piety and love of God by living in accordance to 'His will' in the best way possible. In the following quote, she explains her primary reason for wearing a veil:

In the end, for me, it's an act of obedience. Honestly, if it weren't God who was asking me, why would I do so? (...) I (myself) wouldn't have bothered wearing it. It's true. I wouldn't have changed my style, I mean: I would not have changed. (Zeina, administrative employee, Brussels)

Zeina's account introduces us to a different ethical imaginary. One wherein one's agency is not (only) realised by following one's 'desires', but rather by subjecting oneself to Divine prescriptions, even if the latter implies an active labour on one's bodily dispositions. In the quote above, Zeina even refutes any other 'pleasure' she could derive from veiling. She simply reduces it to its religious functionality: a religious prescription she fulfils as an act of obedience.

Zeina's religious agency is structured in a non-liberal manner, her subjectivity (as Muslim) is realised throughout as the capacity to dutifully subject herself to an ethical code of conduct and strive towards the fulfilment of God's 'requests'. ${ }^{18}$ yet, in discussing Zeina's case, my aim is not to presuppose a dichotomy or contradiction between the ethical agency of veiled and non-veiled women. Several ethnographies in various European countries have indeed started exploring the intersections of liberal and non-liberal modes of subjectivation in the ethical agency of pious Muslims (Fadil, 2008; Jacobsen, 2010). The orthodox Muslim women I interviewed saw, for instance, the hijab both as a means to live as a 'liberated', 'emancipated' woman as well as a means to 'worship God'. Notveiling, furthermore, does not always figure as an aesthetic of the self. 'Up-' and 'downveiling' can equally be an outcome of professional circumstances or educational requirements - especially in Western-Europe, or be linked with practical or even aesthetic reasons. ${ }^{19}$ This picture needs, finally, to be complicated by those pious women I encountered who did not veil, yet saw this practice as a next stage in their ethical conduct (see also Jouili, 2009). The simple fact of not-veiling, thus, does not immediately turn the latter into an aesthetic of the self. What rather makes it into a practice of the self, I suggest, is the manner in which it is tied to one's self-fashioning as a liberal ethical subject, as observed in the case of Leyla. ${ }^{20}$

One could, however, object that this opposition to the veil does not suffice to frame the latter as a self-technique, considering the absence of evident labour (ethical work) involved in it. Whereas various studies have documented the ethical work upon one's affects and corporeality implied in veiling (Mahmood, 2005; Jouili, 2007; Fadil, 2008), this cannot be said with regard to the non-veil. In what follows, I challenge this reading that tends to depict not-veiling as a passive act. I suggest that a Foucaultian anti-essentialist perspective on the 
body, which breaks with the idea of a natural body that is unmediated by any discursive structures, invites us to consider the embodied contours of this practice and the ways in which questioning the hijab can equally imply a labour upon one's affects and sensibilities.

\section{not-veiling as a body practice}

To claim that discourse is formative is not to claim that it originates, causes, or exhaustively composes that which it concedes; rather it is to claim that there is no reference to a pure body which is not at the same time a further formation of that body. (Butler, 1993: 10)

In his seminal essay, Nietzsche, Genealogy, History, Foucault argues in a well-known quote that 'nothing in man - not even his body - is sufficiently stable to serve as the basis for self-recognition or for understanding other men' (Foucault, 1971: 360). Throughout this sentence, he expresses his antiessentialist and anti-humanist understanding of the body, wherein he rejects the idea of a body that 'obeys the exclusive laws of physiology' and that 'escapes the influence of history'. The body, in Foucault's understanding, 'is moulded by a great many distinct regimes; it is broken down by the rhythms of work, rest, and holidays; it is poisoned by food or values, through eating habits or moral laws; it constructs resistances' (Foucault, 1971: 360). Or, as Lois McNay notes, the body figures in this context as the 'most specific point at which the microstrategies of power can be observed' (McNay, 1994: 91).

Foucault's anti-essentialist understanding of the body has been of crucial importance for a critical theoretical enterprise that seeks to unpack the idea of a 'natural' body. These insights have been especially helpful in the field of gender studies, and the way it allowed for a critical deconstruction of the idea of 'natural' sexual differences. The work of Judith Butler stands out here as an important example. In Gender Trouble and Bodies that Matter, she develops the well-known argument that the material basis of sex (and sexual difference) needs to be understood as an effect of the daily reiteration (and citations) of heterosexual regulatory ideals (gender). Such insights are, not only helpful for a critical deconstruction of 'sex' and 'sexual difference', but they can also help us to deconstruct the widely shared liberal assumption that not-veiling figures as a 'natural way of being'. Such a critical posture encourages us indeed to unpack this idea, and to view it as a naturalised effect of a secular-liberal regulatory ideal. The secular regulatory ideal is not gender neutral, but draws on a particular perspective on the (female) body, which views the disclosure of certain bodily parts (such as the hair and face, the figure) as essential for achieving 'womanhood' (see also MacDonald, 2006: 12). The 'power of the secular' seems then to reside in its capacity to naturalise such a distinctive perspective on the note that the

process of

secularisation and modernisation not only signified the problematisation of the Islamic veiling, but the habit or religious dress of nuns also figured as a target of the modernisation processes after the second Vatican council in 1964. For an account of the unveiling of Catholic nuns, see Lafontaine (2008). 
female body, and to represent and grasp the non-veiled body as the natural and 'free' body.

Such a naturalisation of the non-veil can be observed in prevailing liberal accounts that dismiss the hijab not only as a disruption of a neutral or secular space, but also view it as a violation of one's corporeal autonomy or bodily integrity. We see such perspectives expressed by some feminist (and nonfeminist) critiques of the headscarf and (especially) the face-veil - as an oppression of the female body (because of the disclosure of certain bodily parts that are seen as essential for one's individual agency). Leyla, we saw earlier, equally criticised the veil as a sexist 'instrument' that 'annihilates' the personality of a woman, which she explicitly tied to patriarchal structures. Undergirding these accounts lies a conception of the female body as naturally unveiled. Yet simply dismissing such viewpoints that deem the headscarf as an 'oppression' or an infringement upon one's corporeal autonomy as faulty is not enough, I contend, for as long as one fails to equally challenge the hegemonic liberal viewpoint that considers the non-veil as a natural way of being. The challenge resides then not only in demonstrating the active agencial capacities of veiled Muslim women, but also in deconstructing the idea of the non-veil as natural by disclosing the embodied and citational practices behind this conduct, by illustrating its re-enactments and accounting for its performativity. In what follows, I will therefore focus on some accounts wherein not-veiling is framed as a body practice.

Contrary to what might be supposed, problematising the hijab was not always an easy task for my non-veiled respondents. Leyla, we saw above, repeatedly mentioned the insecurities regarding her non-orthodox viewpoints on the hijab and the Muslim tradition at large. Other female interviewees expressed similar hesitations and doubts. Zakia, for instance, a woman in her mid-thirties who worked as translator and lived in Brussels, did not reject the religious value of the hijab, yet she did question the importance attributed to it. These questionings were part of broader interrogations she had, and the many 'incomprehensions' she saw in the prevailing interpretations of the Qur'an and the Sunna. However, while asserting these claims, she also portrayed herself as a 'lost sheep' [brebi égarée] and apologised for her critical remarks: 'I hope I haven't offended you in what I'm telling you today'. Huda equally described the sentiment of 'guilt' she had when she gradually started taking off the hijab: 'in my first year of university (...) I went with a friend to Madrid, and I often took it off there. And sometimes, I really felt guilty and all that... Not only guilty, you see, but it was more like, ehm... I don't want her to think of me as a hypocrite or so. So I put it back on'.

Leyla, Zakia and Huda's ambivalence can firstly be understood as an expression of the sentiment of solitude that stems from their interrogation of the hijab. Refuting the prescription to veil seemed to imply a new posture towards the rest 
of the Muslim community for it also meant, for many, adopting a position of marginality towards the reigning ethical convictions. This sentiment of marginality is clearly observed in the 'guilt' and shame expressed in Huda's account and in Zakia's apology for her critical posture. Such a sentiment of marginality or solitude seems at first glance curious, considering the dominant secular context in Belgium wherein not-veiling passes as the norm. The insecure positions of Leyla, Zakia or Huda illustrate, however, how the constitution of their ethical agency seems to be equally shaped by the orthodoxy within the Muslim tradition. While the dominant liberal-secular context does act as an important structuring grammar, the position of epistemic marginality they adopt illustrates the necessity to account for the complex interactions between these liberal ethical grids and the Muslim orthodoxy in their self-fashioning process.

Some of my interviewees tried to escape this position of marginality by turning the non-veil into a symbolic marker or an identity politics towards the Muslim community. Zohra, a community worker in Brussels who was involved in organising seminars on the liberal Muslim perspectives, explained how she gradually had come to distance herself from the Islamic organisations she was active in as an adolescent. This followed from a sentiment of malaise she experienced in these circles, linked to her unorthodox viewpoints she held concerning the hijab and other practices.

\footnotetext{
The fact that I didn't veil was, for me, a way to evaluate the degree of openness and emancipation in the minds towards this question of veiling. (...) There is a discourse, and there is reality. I believe that there is a discourse, or everyone is carrying that discourse. I never heard anything else as far as I'm concerned [than] that it [the hijab] should be the product of a personal trajectory, that every action will be judged by its intention, that it shouldn't be forced on people etc. But in the implicit, you could always somehow feel: 'what a pity'. And I believe it is condescending, there is a paternalism which bothered me somehow. Because for me Islam is something so much larger than the question to veil or not to veil. (Zohra, community worker, Brussels)
}

Not-veiling appears here as a conscious and active act. Two different, yet interlaced, concerns appear in her justification. Not-veiling firstly reflects Zohra's quest for a 'different' model of piety, as observed in the earlier accounts. By notveiling, Zohra articulates her desire for an Islam that consists of 'more' than ritual practices - as she put it. Yet not-veiling not only reflected her unorthodox viewpoint regarding this practice, it also appears here as an identity practice, a practice through which she opposes the dominant expectancies within the Muslim community. In another part of our interview, she explains: 'When they ask the question: "Are we obliged to wear the headscarf or not", somehow it's: "Is that the price to pay to be recognised, to be loved and to belong to this community, else we are always somehow put aside"'. Zohra's opposition to the veil follows from an opposition to the way the veil became an essential marker of one's Muslim 
21 Craig Calhoun situates this notion of recognition as one of the key issues of identity politics:

'Identity turns on the interrelated problems of selfrecognition and recognition by others' (1994: 20).

22 For an analysis of the ways liberal ethics operate by building on a contrast between the 'liberated' self that is emancipated from culture and religion versus the traditional self or 'organistic creature' that is governed by the context of his culture or religion, see Brown (2006: 163). identity. ${ }^{21}$ Throughout our interview, Zohra repeatedly denounced the tacit coercion she felt to veil in the times of her involvement in Islamic organisations. While these expectations were rarely articulated explicitly, she felt them in the implicit - in the way veiling was viewed as the ultimate pious conduct. Not-veiling thus figures, in the case of Zohra, not only as an ethical practice but also as an identity practice through which she could express a sentiment of 'individuality' vis-à-vis the 'group'. 22

Yet, in order to fully grasp the insecurities of my non-veiled respondents, I contend that it is not enough to view these simply as a mirror of the marginality they describe. Rather, one could also interpret these insecurities as a reflection of the embodied and affective labour that is implied in the supplanting of certain fully ingrained truth-claims (headscarf as essential for Muslim piety) by another set of truth-claims (not-veiling as essential to one's liberal ethical agency). They illustrate Butler's claim of how power operates on a psychic and affective level, and how one's ethical refashioning equally implies an affective refashioning of the self. In making this point, I draw on Hirschkind's insightful comments on the ways the Muslim tradition sits upon an affective household that acts as a 'common ground upon which the discourses of a tradition come to be articulated' (2006: 88). While rational disagreements exist and persist over what constitutes the established norm, Hirschkind looks at the way virtuous speech operates by shaping one's affects, character and attitude according to a distinctive ethical grid (Hirschkind 2006: 14). Hirschkind's latter point on how affective dispositions underlie Muslim pious conduct allows us to shed a different light on the experiences of anxiety and insecurity observed here. It invites us to consider the affective labour that is tied to the questioning of prevalent ethical truth claims, such as the prescription to veil. In order to substantiate this claim, I briefly turn to the story of Huriya, who took off the veil after growing increasingly unconvinced of its religious nature.

Huriya's long cultivation of her piety within the Islamic orthodoxy drastically changed in her late twenties as a result of a number of interrogations she had regarding the Muslim tradition, which would eventually lead to the abandonment of her praxis and her faith in God. A central episode in this conversion from an orthodox religious self-conception to a secular one was her decision to unveil. While this act did not mean the end of her relationship with God - for she maintained her faith for a period after this - it did represent the first secular practice that was visible to the outside world. I deliberately frame this conduct as a secular practice, for unveiling signalled, in Huriya's case, an important phase in this conversion. She portrayed it as a lengthy, difficult and laborious enterprise. Huriya first started questioning the hijab during her university studies. As a student in Arab and Islamic studies, she learned to examine the Islamic hermeneutical tradition in a new way, according to new criteria, different from the ones she had learned in mosque groups. ${ }^{23}$ It is in this same period that 
she decided to investigate the exegetical justifications of this prescription: 'I looked at some old dictionaries, I translated the verse and I realised that: no, it doesn't mention at all the head. I looked at the first tafseer [exegesis], and they didn't mention the head either. (...) When you read the first tafseer, at the level of the words, the language, it's not mentioned. That's when I started crying'. Huriya's exegeses, which lead her to the conclusion that veiling was not a mandatory practice, was not welcomed positively, but rather made her cry. Fear and doubt is how she frames the loss of the ethical value she attached to the headscarf. Fear that her questioning were informed by a wrong reading of the sources, or worse: that they unconsciously reflected a quest for an 'easy way out' - as she put it - from the disciplining religious ethos regime she had been imposing herself for a number of years. Doubt caused by the fact that she was alone in her questioning, as her husband and friends initially opposed her challenges. Taking off the hijab was not experienced as an easy act by Huriya. It was rather a practice she imposed upon herself as she grew increasingly unconvinced of its religious nature. ${ }^{24}$ She repeatedly stressed throughout our interview her love for hijab and how she 'felt good' wearing it. After months of anxiety, emotional distress and deliberation, she finally took the step to unveil:

It was on a day when I was praying while walking. It was very warm, and I saw many veiled girls. I looked at them, dressed very warmly, with a lot of make-up on, very vulgar. I looked at their husbands, in shorts. I said to myself: 'what's this? What's with all these contradictions?' And then I realised that nobody would talk to me because I was veiled. And I didn't feel in line with those people. So, while I was walking in the streets, I performed the salaat istikhara, and I took my veil off in the middle of the Rue Neuve. I took it off like that! I didn't care! I said to myself: I don't give a damn about what people think. For me, it was very hard (...). So now that I felt the courage to do it, I did. (Huriya, researcher, Brussels)

Huriya expresses here her opposition to a prevailing model of piety (represented here by the Muslims she describes) that she considered to be full of contradictions. A model of piety that, to her, is primarily focussed on the outward behaviour and the maintenance of a particular dress-code, rather than on the meaning of these practices and their consistency (i.e. veiling and wearing make-up, wearing shorts). Unveiling, therefore, allows her to distance herself from a reigning model of piety, from the 'other' Muslims she considered insincere. Also, significant, is how this practice is accompanied by the recitation of the salaat al-istikhara, which turns it into pious conduct. ${ }^{25}$ Unveiling thus becomes more than an outward expression of her inner convictions, it figures as an embodied enactment of those convictions. This turns the non-veil into a body practice that is an integral part of her ethical self-fashioning process.

Yet taking off the headscarf was not a simple endeavour, nor was it experienced as a 'liberating' practice (as often presupposed by secular normativity). Throughout our interview, Huriya repeatedly insisted that her decision to unveil was preceded and also illustrates the structuring role of Arab and Islamic studies and the particular epistemological tradition that is transmitted in a university context. While this has not been the object of my analysis, it was striking to observe that both Leyla and Huriya were students of Arab philology.

24 We see here, yet again, the articulations of a liberal notion of the self wherein Huriya's rational agency figures as ultimate guideline in her ethical self-

fashioning process, as opposed to

Zeina's non-liberal ethics observed earlier wherein her ethical conduct was ultimately guided by a heteronomous agent, that is, God's Will.

25 Salat Istikhara or the consultation prayer is performed by pious Muslims in cases of hesitation or doubt about upcoming decisions. It is believed that performing this prayer will help the believer in his or her 
decision by inclining them towards a particular direction, either through intuition or through dreams (see also Mittermaier, 2010). followed by a lengthy and difficult labour upon herself and embodied disposition, and that she needed to find a new way to relate to her environment and her body. As a veiled woman, for a long time she had felt protected from the sexual objectification of her body. Yet after removing her veil, her sexuality seemed to lay there naked, for to anyone to see. It took her time before she stopped associating her unveiled body with a sexually marked, promiscuous body:

I wanted to affirm myself as an intellect, and not as a body. I didn't want to be a body. You know, when I took my veil off, I completely neglected myself. I put up some weight and everything (...). I really experienced taking off my veil badly, because I really felt good wearing it. (Huriya, researcher, Brussels)

Huriya's account offers insightful evidence of how one's self-conception is embodied and how a transformation of one's self-conception equally implies the transformation of the way one relates to one's body. Taking off the veil implied cultivating a new relationship to her body, relating to the visible parts of her body in a new manner, refashioning her sensitivity towards the gaze of the outside world on those bodily parts that had until then remained covered, as part of her individual 'privacy'. While recent scholarship has illustrated how such bodily refashioning is implied in the project of pious ethical reform by orthodox Muslims (Mahmood, 2005), Huriya's account illustrates how the movement away from religion can be equally tied with an active refashioning of one's embodied dispositions. A difference, however, appears in the teleology or ethical aim of this selfpractice. While orthodox Muslim interlocutors situated this self-labour as a means to obey God, Huriya rationalises this self-discipline through liberal narratives of authenticity and autonomy.

Such insights seem counterintuitive, for they contradict the dominant (secular) views that locate self-discipline in the realm of the religious ethos and present a secular lifestyle as effortless. Yet accounts like those of Huriya help us to unravel this idea and disclose the practices of the self that are linked to the project of becoming a liberal-secular subject. More importantly, Huriya's account also invites us to explore the question under which conditions the materialisation of a regulative ideal implies an active effort upon one's embodied dispositions, and when - at the contrary - it occurs through daily reiterations and enactments that are experienced (and framed) as 'natural' and 'effortless'.

\section{conclusion: unveiling the normalising powers of the secular}

The headscarf controversies in various European countries have resulted in a body of literature that engages with the disciplining procedures towards veiled Muslim women. These discussions have also set out a context wherein non-veiled Muslim women are rarely addressed as object of research, and when they are, observed as secular Muslims or the 'silent majority'. In this paper, I have 
argued for the necessity to acknowledge the practical dimensions behind the non-veil, and the way that unveiling can figure as a bodily practice that is intimately tied to the process of ethical self-fashioning. Accounts of second-generation Maghrebi women living in Belgium who do not veil have been analysed to this extent. In the first part of this paper, I have tried to unpack the ethical substance of such discursive interrogations and pointed to the ways in which they were intertwined with the enactment of a liberal subjectivity model. In the second part, I have also examined the embodied dimension of this problematisation, which appeared through the labour upon one's affect and bodily dispositions that this refusal of the hijab, or the act of unveiling, implied.

While preliminary and highly exploratory, these insights fit within a recent stream of literature that examines the operation of 'the secular' by unfolding the normative assumptions and disciplinary modes undergirding it (Asad, 2003). The importance of this perspective lies, as has already been stated above, in the way it encourages a de-naturalisation of the secular, which is too often conceptualised as an ontologically neutral zone, abstracted from any power relations or productive capacity. Accounts like those of Huriya, Huda or Leyla invite us, on the other hand, to explore the ethical and affective work that is implied in notveiling, and to disclose the bodily practices that are tied to it. By examining the 'non-veil', and situating it as an ethical conduct, this paper has therefore firstly sought to identify some practical and affective dimensions of this act that are too rarely identified as such. Yet such insights do not only apply to the 'non-veil', but to a wider range of corporeal and ethical practices that pertain to the domain of 'the secular', which are often grasped through generic negative categories, such as 'non-practising'. These taxonomies not only fail to grasp the discursive and affective labour that is implied in these conducts - as the cases of the non-veiled women in this paper show, but their passive enunciation also presupposes the idea of a 'natural body'. Whereas the notion of 'practising' suggests the presence of an active conduct (and discipline), 'non-practising' presupposes non-conduct, or a natural state of being that can be lived once religious traditions and ethics have crumbled. Unpacking the operations of the secular therefore implies searching for new metaphors and vocabularies that would allow us to grasp the 'naturalized' operations of the secular. Such efforts furthermore also sit on a renewed engagement with theories of the body, and a continuation of the genealogical effort of offering a 'critical ontology' of the human body, as has most systematically been elaborated within feminist and post-structuralist theoretical scholarship over the past 20 years (Butler, 1990, 1993; Grosz, 1994).

Before concluding this paper, I would like to return to the challenges confronting the analyst who seeks to understand the complexities of the agency of those women who are viewed in the current Western-European context as the 'good' and 
26 The usage of the terms 'good' and 'bad' reflects here Mahmood Mamdani's (2004) good Muslim/ bad Muslim

dichotomy, which he views as a primal distinction that was developed in the post-9/11 conjuncture to differentiate Muslims in the basis of their allegiance towards the West in a new geo-political conjuncture.

27 The well-known Flemish moral philosopher from the University of Ghent, Etienne Vermeersch, published a paper in March 2010 in support of the prohibition of the headscarf. His argumentation consisted, among others, of a theological contestation of the Islamic nature of the headscarf, with reference to liberal Muslim scholars such as Malek Chebel. docile counterpart of their 'bad sisters', the veiled women. ${ }^{26}$ This question becomes even more salient in a postcolonial European context where oppositions to the hijab are mobilised to legitimise disciplining discourses and measures targeting Muslim women. This becomes apparent in the way arguments objecting to the mandatory feature of the hijab are deployed to justify prohibitions of the headscarf - even when its holders oppose such measures. ${ }^{27}$ This has led some scholars to examine the political location of 'secular' or 'liberal' Muslims, and the way challenging the Muslim orthodox model of piety works together with the regulatory powers of the secular (Mahmood, 2006; Mas, 2006; Fernando, 2009). While earlier I criticised the risk such perspectives entail for a complex understanding of the agency of the women who refuse the hijab, this issue nevertheless remains an important one for those who, like myself, remain committed to postcolonial feminist perspectives. My purpose in this conclusive note is not to disqualify the legitimacy of liberal critique upon the hijab (which is not my role as analyst), but rather to consider under which circumstances such a critique can be expressed without re-enacting the regulatory powers of the secular.

One way of expressing such a critique has been to account for these tensions and to take them as a point of departure in the examination of the hermeneutical and self-naming practices of 'secular' and 'liberal' Muslims. This line of reasoning can be found in the work of Ruth Mas (2006) and the fine analysis she offers of the emergence of secular Muslims in France. In an article on two petitions launched by two French movements of secular Muslims (Mouvement des Musulmans Lä̈ques de France and Association des Manifestes de Liberté), Mas unfolds the ways these mobilisations are committed to a reappropriation of the categories 'Muslim' and 'Islam' that are too often associated with violence or oppression in the current political debates. She describes how such positions depart from a multiple critique (Cooke, 2000): a critique on the negative representations of Islam in the dominant French public, on the one hand, and a critique on what they consider as 'fundamentalist', exclusivist and misogynist tendencies within the Muslim community on the other. Such a multiple critical posture was illustrated at the outset of this paper through the case of Saloua, whose refusal to write on veiled women signalled both a refusal of dominant essentialist representations of Muslims as well as a refusal of the normative weight of the hijab on Muslim practice. While she views these petitions as attempts to resist the prevailing categorisations and stereotypes, that is, naming themselves secular Muslim as a way to insist on their difference from the dominant French culture while advocating an Islam in compliance with the grammars of French Laïcité (2006: 604), Mas nevertheless questions the 'discursive agency' of these petitions and their capacity to counter exclusionary tendencies towards Muslims. She refers to the way such self-naming practices sit in the continuity of a (neo)colonial legacy and French governmental practices that 'interpellate' Muslims as 'others', and thus compel such self-naming 
practices as 'secular' or 'cultural' Muslim to claim secular allegiance. While Mas does not question the 'authenticity' or 'legitimacy' of the petitioners, she nevertheless does insist on the importance of acknowledging 'the role that power plays in the epistemological conclusion that we make about their selfconstitution' (2006: 604). For Mas, the critical potential of these petitioners to 'rupture both French political designations and normative designations by Muslims of what Islam or Muslims are' will be dependent of their capacity to account for this historical genealogy and to 'confront the imperial investments in history' (2006: 611).

Mas' insistence on the necessity to account for the historical location of such a self-constitution as 'liberal' or 'secular' Muslim provides a first way to avoid enhancing the repressive facets of the secular. Yet, such an endeavour is not sufficient, I suggest, to also challenge the hegemonic components of the secular, and more particularly its normalising capacities that consist of the naturalisation of a particular notion of the self. This assertion is fuelled by the observation of some recent attacks on the hijab articulated by scholars who have been at the vanguard of postcolonial scholarship. Marnia Lazreg's Questioning the Veil (2009) figures as a good illustration in this respect. Through a highly personal account, she seeks to demarcate herself from the emergence of the veil that she considers as 'an essential part of a trend that is largely organized and thus detrimental to women's advancement' (2009: 3 - her emphasis). Interestingly, though, Lazreg's account is informed by a deep awareness of the 'context' of her intervention. An awareness that appears through her references (and oppositions) to the current imperial investments and restrictive policies towards veiled Muslim women, as well as the hesitant tone with which she starts her letters: 'Writing these letters was not an easy task: it required me to say things I normally would not have said about issues that had troubled me in the past but which I let alone with the hope that they might just come to pass' (2009: ix). Despite this context, she nevertheless writes these letters to 'break the silence' she imposed upon herself for too long. Parts of her argument against the veil rely heavily on her understanding of this sartorial practice as sexist and oppressive. While she acknowledges the multiple significances given to it by its wearers (including cultural pride, modernity, emancipation, piety), she contends that the latter cannot outweigh the historical signification of the veil as 'part of a historic power configuration in which men, with or without religious fervour, have found sustenance for their identity as males' (2009: 125).

Lazreg's account is interesting in the awareness she displays of the historical and governmental practices tied to veiling and unveiling. Yet her analysis falls short in her capacity to account for the agency of veiled and non-veiled in an equal manner: whereas veiled women are viewed as deniers of, and even complicit with, a history of oppression, not-veiling is viewed as 'women's victory 
over a custom that inflects their thinking about themselves as human being' (2009: 130 - her emphasis). At the heart of her argument lies, I suggest, a naturalisation of a liberal-humanist notion of agency, which rests on a particular ontology of the female body. The latter is also confirmed through her numerous descriptions of the veil as oppressive for one's bodily integrity and psychological well-being. She speaks of the veil as 'inconvenient in hot weather', as clothing that 'blunts sensory perception' and that is 'physically constraining' (Lazreg, 2009: 104-105). Questioning the veil is therefore not problematic in its failure to account for the repressive facets of secular and neocolonial modes of governance, but rather for its failure to denaturalise a particular notion of the self and one's body that is reiterated and enacted throughout the regulatory powers of the secular.

One of the main tasks of a critical feminist and postcolonial perspective is the capacity to offer a 'critical ontology of the self' (Foucault). By this I mean the challenge to identify the contours of, and historicise the notion of, the self and one's body, which has become naturalised in our understanding of humanity (and womanhood). This call for a critical ontology of the self is neither a way to discard the liberal subjectivity model undergirding an interrogation of the hijab, nor a way to suggest that veiled Muslim women figure as the only 'authentic' postcolonial Muslim subjects. It is rather a method, an ethic, an attitude, that consists of the identification of the practices of the self undergirding a particular mode of being and to account for the 'the different modes by which, in our culture, human beings are made subjects' (Foucault, 1982: 208). This, not in order to do away with those modes of subjectivation, but rather to situate them (in their specificity) and render other 'modes of being' intelligible and meaningful. The power of secular lies, on the other hand, in its capacity to conceal these practices of the self and to regulate (religious) conduct, practices, bodies and thought according to naturalised conceptions of the self. An interrogation of the hijab that fails to acknowledge the specific subjectivity model upon which it rests risks, therefore, not only to sustain, but also to contribute to the hegemonic powers of the secular. This occurs not by repressing the hijab, nor by prohibiting veiled women to work or attend classes, but merely by re-enacting the simple (and hegemonic) idea that not-veiling or unveiling remains the only 'true' way to live as a liberated and emancipated (female) subject.

\section{acknowledgements}

First drafts of this paper have been written during my Jean Monnet Postdoctoral Fellowship (2008-2009) at the Robert Schuman Center for Advanced Studies of the European University Institute. I am grateful to the two anonymous reviewers, Schirin Amir-Moazami, Sarah Bracke, Christine Jacobsen, Maleiha Malik for their comments, insightful critiques and suggestions and Melissa Dichter for her valuable proofreading. 


\section{author biography}

Nadia Fadil studied sociology and anthropology at the Catholic University of Leuven (KULeuven), Belgium, and holds a PhD in Sociology from the same university. She is currently affiliated at the Centre for Sociological Research of the KULeuven as a Postdoctoral Fellow of the Research Foundation Flanders (FWO). Her research interests revolve around questions of subjectivity and embodiment, secular governmentality, liberalism and multiculturalism focused on the presence of Muslims in Europe.

\section{references}

Ahmed, L. (1992) Women and Gender in Islam. Historical Roots of a Modern Debate, New Haven \& London: Yale University Press.

Al-Ali, N. (2000) Secularism, Gender and the State in the Middle-East, Cambridge: Cambridge University Press.

Amiraux, V. (2003) 'Discours Voilés Sur Les Musulmanes En Europe: Comment Les Musulmans Sont-ils Devenus Des Musulmanes?' Social Compass, Vol. 50, No. 1: 85-96.

Amiraux, V. (2006) 'Speaking as a Muslim: Avoiding religion in French public space' in Amiraux, V. and Jonker, G. (2006) editors, Politics of Visibility. Young Muslims in European Public Spaces, Bielefeld: Transcript.

Amir-Moazami, S. (2007) Politisierte Religion. Der Kopftuchstreit in Deutschland und Frankreich, Bielefeld: Transcript.

Amir-Moazami, S. and Salvatore, A. (2003) 'Gender, generation, and the reform of tradition: from muslim majority societies to Western Europe' in Allievi, S. and Nielsen, J. (2003) editors, Muslim Networks and Transnational Communities in and Across Europe, Leiden \& Boston: Brill.

Asad, T. (1986) The Idea of an Anthropology of Islam, Occasional Papers Series, Center For Contemporary Arab Studies, Washington: Georgetown University.

Asad, T. (1993) Genealogies of Religion. Discipline and Reason of Power in Christianity and Islam, Baltimore \& London: John Hopkins University Press.

Asad, T. (2003) Formation of the Secular. Christianity, Islam and Modernity, Stanford: Stanford University Press.

Asad, T. (2006) 'Trying to understand French secularism' in De Vries, H. and Sullivan, E.L. (2006) editors, Political Theologies. Public Religions in a Post-secular World, New York: Fordham University Press.

Babès, L. (2004) Le Voile Demystifié, Paris: Editions Bayard.

Blommaert, J. and Verschueren, J. (1992) Het Belgische Migrantendebat. De pragmatiek van de abnormalisering, Antwerpen: International Pragmatics Association.

Bracke, S. (2008) 'Conjugating the modern/religious, conceptualizing female religious agency: contours of a "post-secular" conjuncture' Theory, Culture \& Society, Vol. 25, No. 6: 51-67.

Brown, W. (2006) Regulating Aversion. Tolerance in the Age of Identity and Empire, Princeton and Oxford: Princeton University Press.

Butler, J. (1990) Gender Trouble. Feminism and the Subversion of Identity, London: Routledge.

Butler, J. (1993) Bodies that Mattter. On the Discursive Limits of 'Sex', New York \& London: Routledge.

Calhoun, C. (1994) Social Theory and the Politics of Identity, London: Blackwell. 
Coene, G. and Longman, C. (2008) 'Gendering the diversification of diversity. The Belgian hijab (in) question' Ethnicities, Vol. 8, No. 3: 302-321.

Cooke, M. (2000) 'Multiple critique. Islamic feminisim rhetorical strategies' Nepantia: Views from South, Vol. 1, No. 1: 91-110.

De Vries, H. and Sullivan, ع.L. (2006) editors, Political Theologies. Public Religions in a Post-secular World, New York: Fordham University Press.

عl-Guindi, F. (1999) Veil. Modesty, Privacy and Resistance, Oxford \& New York: Berg.

Fadil, N. (2008) Submitting to God, Submitting to the Self. Secular and Religious Trajectories of Second Generation Maghrebi in Belgium, Leuven: KULeuven (unpublished disseration).

Fanon, F. (1964) 'Algeria unveiled' in Oglesby, C. (1969) editor, The New Left Reader, New York: Grove.

Fernando, M.L. (2009) 'Exceptional citizens: secular Muslim women and the politics of difference in France' Social Anthropology, Vol. 17, No. 4: 379-392.

Foucault, M. (1971) 'Nietzsche, Genealogy and History' in Rabinow, P. and Rose, N. (1971) editors, The Essential Foucault: Selections from Essential Works of Foucault, 1954-1984, New York: The New Press.

Foucault, M. (1998 [1976]) The History of Sexuality 1: The Will to Knowledge, London: Penguin Books.

Foucault, M. (1993 [1980]) 'About the beginning of the hermeneutics of the self. Two lectures at Dartmouth' Political Theory, Vol. 21, No. 2: 198-227.

Foucault, M. (1982) 'Afterword. The Subject and Power' in Dreyfus, H.L. and Rabinow, P. (1982) editors, Michel Foucault. Between Structuralism and Hermeneutics, Brighton: Harvester press.

Foucault, M. (1992 [1984]) The History of Sexuality 2: The Use of Pleasure, London: Penguin Books.

Gökariksel, B. (2009) 'Beyond the officially sacred: religion, secularism and the body in the production of subjectivity' Social \& Cultural Geography, Vol. 10, No. 6: 657-665.

Göle, N. (1993) Musulmanes et modernes. Voile et civilisation en Turquie, Paris: La Découverte/ Poche.

Grosz, ع. (1994) Volatile Bodies. Toward a Corporeal Feminism, Bloomington \& Indianapolis: Indiana University Press.

Haraway, D. (1988) 'Situated knowledges. The science question in feminism and the privilege of partial perspective' Feminist Studies, Vol. 14, No. 3: 575-599.

Herrera, L. (2000) 'Downveiling: shifting socio-religious practices in Egypt' International Institute for the Study of Islam in the Modern World, Newsletter 6 (October 2000): 1-32.

Hirschkind, C. (2006) The Ethical Soundscape. Cassette Sermons and Islamic Counterpublics, New York: Columbia University Press.

Hollywood, A. (2004) 'Gender, agency, and the divine in religious historiography' The Journal of Religion, Vol. 84, No. 4: 514-528.

Jacobs, D. (1998) Nieuwkomers in de Politiek. Het parlementair debat omtrent kiesrecht voor vreemdelingen in Nederland en België (1977-1997), Gent: Academia Press.

Jacobs, D. and Swyngedouw, M. (2002) 'The extreme-right and enfranchisement of immigrants: main issues in the public "debate" on integration in Belgium' Journal of International Migration and Integration, Vol. 3: 3-4.

Jacobsen, C.M. (2010) Islamic Traditions and Muslim Youth in Norway, Leiden: Brill.

Jouili, J.S. (2007) Devenir pieuse: Femmes musulmanes en France et en Allemagne entre réforme de soi et quête de reconnaissance, Unpublished Thesis, Ecole des Hautes Etudes en Sciences Sociales \& Europa-Universität Viadrina für Kulturwissenschaften: Paris \& Frankfurt-0der.

Jouili, J.S. (2009) 'Negotiating secular boundaries: pious micro-practices of Muslim women in French and German public spheres' Social Anthropology, Vol. 17, No. 4: 455-470. 
Jouili, J.S. and Amir-Moazami, S. (2006) 'Knowledge, empowerment and religious authority among pious Muslim women in France and Germany' Muslim World, Vol. 96, No. October: 617-642.

Kanmaz, M., Navahandi, F. and Battui, M. (2004) Moskeeën, imams en islamleerkrachten in België. Stand van zaken en uitdagingen, Brussel: Koning Boudewijnstichting.

Kenjanlioglu, D.B. and Oguzhan, T. (2009) 'Regimes of un/veiling and body control: Turkish students wearing wigs' Social Anthropology, Vol. 17, No. 4: 424-438.

Kepel, G. (1994) A l'Ouest d'Allah, Paris: Editions du Seuil.

Khosrokhavar, F. (1997) I'Islam des Jeunes, Paris: Flammarion.

Lafontaine, L.M. (2008) 'Out of the cloister. unveiling to better serve the Gospel' in Heath, J. (2008) editor, The Veil. Women Writers on Its History, Lore and Politics, Berkeley: University of California Press.

Lazreg, M. (1994) The Eloquence of Silence: Algerian Women in Question, London: Routledge.

Lazreg, M. (2009) Questioning the Veil: Open Letters to Muslim Women, Princeton: Princeton University Press.

Longman, C. (2003) 'Over our heads? Muslim women as symbols and agents in the headscarf debate in flanders, Belgium' Social Justice: Anthropology, Peace and Human Rights, Vol. 4, No. 3-4: $300-332$.

MacDonald, M. (2006) 'Muslim women and the veil' Feminist Media Studies, Vol. 6, No. 1: 7-23.

Mahmood, S. (2001) 'Feminist theory, embodiment, and the docile agent: some reflections on the Egyptian Islamic revival' Cultural Anthropology, Vol. 16, No. 2: 202-236.

Mahmood, S. (2005) Politics of Piety. The Reform of the Feminist Subject, Princeton \& Oxford: Princeton University Press.

Mahmood, S. (2006) 'Secularism, hermeneutics, and empire: the politics of Islamic reformation' Public Culture, Vol. 18, No. 2: 323-347.

Mamdani, M. (2004) Good Muslim, Bad Muslim. America, the Cold War, and the Roots of Terror, New York: Three Leaves Press. Doubleday.

Mas, R. (2006) 'Compelling the Muslim subject: memory as post-colonial violence and the public performativity of "secular and cultural islam"' Muslim World, Vol. 96: 585-616.

McNay, L. (1994) Foucault. A Critical Introduction, Cambridge: Polity Press.

Mernissi, F. (1975) Beyond the Veil. Male-Female Dynamics in Modern Muslim Society, New York: Wiley.

Mir-Hosseini, Z. (2007) 'The politics and hermeneutics of hijab in Iran: from confinement to choice' Muslim World Journal of Human Rights, Vol. 4, No. 1, Article 2.

Mittermaier, A (2010) Dreams that Matter Egyptian Landscapes of the Imagination, Berkeley: University of California Press, forthcoming.

Moors, A. (2009) 'The Dutch and the face-veil: the politics of discomfort' Social Anthropology, Vol. 17, No. 4: 393-408.

Moors, A. and Tarlo, $\varepsilon$. (2007) 'Introduction' Fashion Theory, Vol. 11, No. 2/3: 133-142.

Navaro-Yashin, y. (2002) 'The market for identities: Secularism, Islamism, commodities' in Kandiyoti, D. and Saktanber, A. (2002) editors, Fragments of Culture: The Everyday in Modern Turkey, London: Tauris, pp. 221-253.

Oglesby, C. (1969) editor, The New Left Reader, New York: Grove.

Panafit, L. (1999) Quand le droit écrit l'Islam. L'Intégration Juridique de l'Islam en Belgique, Bruxelles: Paris.

Peter, F. (2006) 'Individualisation and religious authority in Western European Islam. A review essay' Journal of Islam and Christian-Muslim Relations, Vol. 17, No. 1: 105-118.

Rahbari, R. (2000) 'Unveiling Muslim women: a trajectory of post-colonial culture' Dialectical Anthropology, Vol. 25, No. 3-4: 321-332. 
Read, J.G. and Bartkowski, J.P. (2000) 'To veil or not to veil? A case study of identity negotiation among Muslim women in Austin, Texas' Gender \& Society, Vol. 14, No. 3: 395-417.

Reath, A. (2006) Agency and Autonomy in Kant's Moral Theory, Oxford: Clarendon Press and Oxford University Press.

Rose, N. (1999) Powers of Freedom. Reframing Political Thought, Cambridge: Cambridge University Press.

Roy, 0. (2000) 'L'individualisation dans l'islam européen contemporain' in Dassetto, F. (2000) editor, Paroles d'islam: Individus, sociétés et discours dans l'islam européen contemporain, Paris: Maisonneuve-Larose.

Saint-Blancat, C. (1997) L'islam de la diaspora, Paris: Bayard Editions.

Scott, J.W. (2007) Politics of the Veil, Princeton: Princeton University Press.

Taylor, C. (1989) Sources of the Self: The Making of the Modern Identity, Cambridge: Cambridge University Press.

Venel, N. (2004) Musulmans et Citoyens, Paris: Presses Universitaires France.

Yegenoglu, M. (1998) Colonial Fantasies: Towards a Feminist Reading of Orientalism, Cambridge: Cambridge University Press.

Yuval-Davis, N. (1997) Gender and Nation, London: Sage Publications.

Zemni, S. (2009) Het Islamdebat, Antwerpen: Epo.

doi: $10.1057 / f r .2011 .12$ 